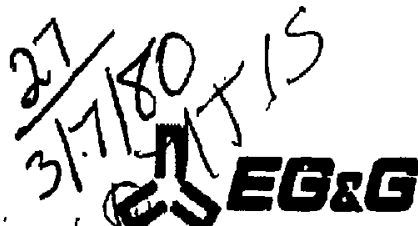

UCRL.-15172

Enorgy Mosuuremonts Croup

\author{
TECHNICAL EVALUATION OF THE ELECTRICAL, \\ INSTRUMENTATION, AND CONTROL DESIGN ASPECTS \\ OF THE \\ OVERRIDE OF CONTAINMENT PURGE VALVE ISOLATION \\ AND OTHER ENGINEERED SAFETY FEATURE SIGNALS \\ FOR THE \\ FORT CALHOUN NUCLEAR POWER PLANT
}

(DOCKET $50-285)$

JANUARY 1980

SAN $-L \cdot 809027$

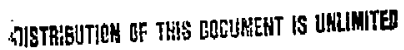




\section{TECHNICAL EVALUATION OF THE ELECTRICAI. INSTRUMENTATION, AND CONTROL DESIGN ASF CTS OF THE OVERRIDE OF CONTAINMENT PURGE VALVE ISOLATION AND OTHER ENGINEERED SAFETY FEATURE SIGNALS FOR THE PORT CALHOUN NUCLEAR POWER PLANT}

(DOCKET $50-285)$

by

0. B. Hackett

Approved for Publication
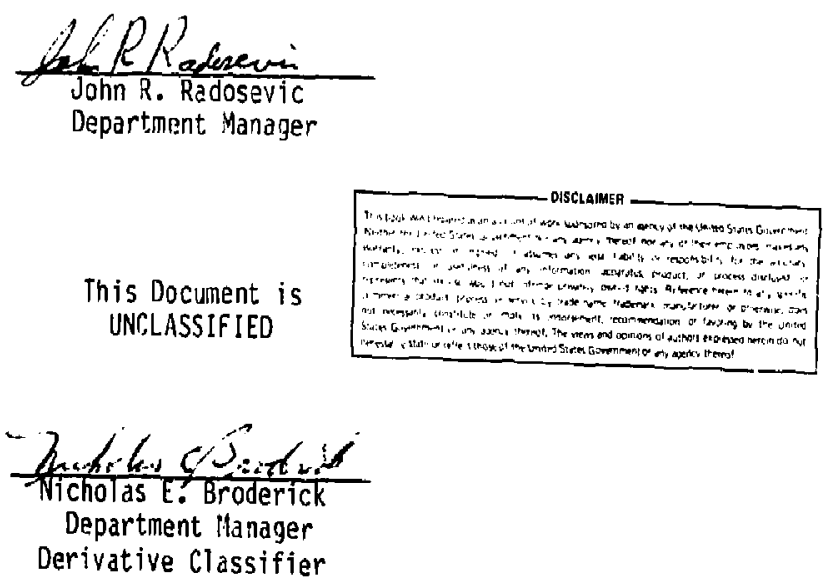

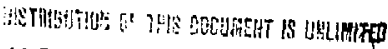
Work Performed for Lawrence Livermore Laboratory under U.S. Department of Energy Contract No. DE-ACO8-76 NVO 1183. 


\section{ABSTRACT}

This report documents the technical evaluation of the electrical, instrumentation, and control design aspects of the override of containment purge valve isolation and other engineered safety feature signals for the Fort CaThoun nuclear power plant. The review criteria are based on IEEE Std-279-1971 requirements for the safety signals to all purge and ventilation isolation valves. This report is supplied as part of the Selected Electrical, Instrumentation, and Control Systems Issues Pragram being conducted for the U. S. Nuclear Regulatory Comission by Lawrence Livermore Laboratory. 
FOREWORD

This report is supplied as part of the Selected Electricat, Instrumentation, and Control Systems Issues (SEICSI) Program being conducted for the U. S. Nuclear Regulatory Commission, Office of Nuclear Reactor Regulation, Division of Operating Reactors, by Lawrence Livermore Laboratory, Field Test Systems Division of the Electronics Engineering Department.

The U. S. Nuclear Regulatcry Cormission funded the work under an authorization entitled "Electrical, Instrumentation and Control System Support," B\&R 201904031 , FIN A-0231.

The work was performed by EG\&G, Inc., Energy Measurements Group, San Ramon Operations, for Lawrence Livermore Laboratory under U. S. Department of Energy contract number OE-AC08-76NV01183. 
TABLE OF CONTENTS

$\underline{\text { Page }}$

1. InTRODUCTION . . . . . . . . . . . . . . 1

2. eVAluation OF FORT CALHOUN NUCLEAR PONER PLANT. . . . 3

2.1 Review Criteria . . . . . . . . . . . . . 3

2.2 Containment Ventilation Isolation Circurts Design Description........... . I 4

2.3 Containment Ventilation Isolation System Design Evaluation. .......... . 5

2.4 Other Engineered Safety Feature System Circuits . . 6

3. CONCLUSIONS . . . . . . . . . . . . . 7

REFERENCES . . . . . . . . . . . . . 9 
TECHNICAL EVALUATION OF THE ELECTRICAL, INSTRUMENTATION, AND CONTROL DESIGN ASPECTS

OF

THE OVERRIDE OF CONTAINMENT PURGE VALVE ISOLATION AND

OTHER ENGINEERED SAFETY FEATURE SIGNALS

FOR

THE FORT CALHOUN NUCLEAR POWER PLANT

(Docket No. 50-285)

D. B. Hackett

EG\&G, Inc., Energy Measurements Group, San Ramon Operations

1. INTRODUCTION

Several instancies have been reported where automatic closure of the containment ventilation/purge valves would not have occurred because the safety actuation signals were either manually overridden or blocked during normal plant operations. These events resulted from procedural inadequacies, design deficiencies, and lack of proper management controls. These events also brought into question the mechanical operability of the containment isolation valves themselves. These events were determined by the U. S. Nuclear Regulatory Commission (NRC) to be an Abnormal Occurrence (\#78-5) and were, accordingly, reported to the U. S. Congress.

As a follow-up on this Abnormal Occurrence, the NRC staff is reviewing the electrical override aspects and the mechanical operability aspects of containnent purging for all operating power reactors. On November 28, 1978, the NRC issued a letter entitied "Containment Purging During Nomal Plant Operation" ${ }^{1}$ to all boiling water reactor (BWR) and 
pressurized water reactor (PUR) licensees. In a letter ${ }^{2}$ dated December 28 , 1978, a letter ${ }^{3}$ dated February 8, 1979, and a letter ${ }^{4}$ dated April 12, 1979, the Omaha Public Power District (OPPO), the licensee for the Fort Calhoun nuclear power plant, replied to the NRC generic letter. The licensee met ${ }^{5}$ with the ARC in Washington, D. C. on August 23, 1979 and participated in a conference call on October 25, 1979 to further discuss the plant status.

This document addresses only the electrical, instrumentation, and control (EI\&C) design aspects of the containment ventilation isolation (CVI) and other engineered safety features (ESFs). 


\section{2. eVAluation OF FORT CALHOUN NUCLEAR POHER PLANT}

\subsection{REVIEW CRITERIA}

The primary intent of this evaluation is to determine if the following NRC staff criteria are met for the safety signals to all purge and ventilation isolation valves:

(1) Criterion no. 1--The overriding* of one type of safety actuation signal (e.g., radiation) must not cause the blocking of any other type of safety actuation signal (e.g., pressure) to the isolation valves.

(2) Criterion no. 2--Sufficient physical features (e.g., key lock switches) are provided to facilitate adequate administrative controls.

(3) Criterion no. 3--The system-level annunciatiun of the overridden status is provided for every safety system impacted when any override is active.

Incidental to this review, the following additional NRC staff design criteria were used in the evaluation:

(1) Criterion no, 4---0iverse signals should be provided to initiate isolation of the containment ventilation system. Specifically, containment high radiation, safety injection actuation, and containment high pressure should automatically initiate CVI. This is in conformance with Branch Technical Position 6.4 of Section 6.2 .4 of the Standard Review Plan.

\footnotetext{
*The following definition: is given for clarity of use in this evaluation:

Override: The signal is still preseit, and it is blocked in order to perform a function contrary to the signal.
} 
(2) Criterion no. 5-- The instrumentation and control systems provided to initiate CVI should be designed and qualified as safety-grade equipment.

(3) Criterion no, 6--The overriding or resetting* of the isolation actuation signal should not cause the automatic reopening of any isolation/purge valve.

\subsection{CONTAINMENT VENTILATION ISOLATION CIRCUITS DESIGN DESCRIPTION}

Fort Calhoun nuclear power plant has two ESF trains which can cause isolation of the containment ventilation system. Train $A$ controls the two inboard containment ventilation valves, and Train B controls the two outboard isolation valves. The initiating contacts for each train are described below:

(1) Automatic Contacts

(a) Containment high-radiation (one out of five $\log i c)$.

(b) Safety injection actuation.

(c) Containment spray actuation.

(d) Containment isolation activation.

(?) Manual Contacts

Emergency operate switch (includes containment isolation actuation, safety injection actuation, and containment spray actuation).

The CVI valves controlled by one train also have derived signals from the other train as backup isolation signals. There are no reset or override switches in the CVI system.

* The following definition is given for clarity of use in this evaluation:

Reset: The signal has come and gone, and circuit is being cleared in order to return it to the nomal condition. 
When a monitored plant condition (or manual input) calls for isolation, electric power is lost to the slave relays (e.g., "I"). Contacts of the slave relays open to remove electric power from the solenoid valves, causing the isolation valves to close.

The CVI valve-solenoid valves must remain energized in order for the isolation valve to remain open. The slave relay circuit contains a seal-in contact to maintain electric power to it as long as a CVI signal is not present. With a CVI signal present, the valves will not remain open and cannot even be opened by their manual switch.

Clearing the initiating isolation signal will clear the CVI signal. However, the isolation valves will not and cannot automatically reopen. Their manual switch must be reinitiated to the "open" position in order to reopen them.

The containment high-radiation monitors have a reset switch, as defined in this report. The high-radiation signal must be manually reset to be cleared.

\subsection{CONTAINMENT VENTILATION ISOLATION SYSTEM DESIGN EVALUATION}

In response to this issue, the operation of the containment ventilation purge valves at the Fort Calhoun nuclear power plant is being limited to less tinan 90 hours per year on an interim basis. Venting is being performed through a two-inch vent line. Both the CVI and tha contaiment isolation signals will close the isclation valves on this two-inch vent line. The CVI actuation systen contains no resets or overrides. We conclude that NRC staff criterion nos. 1,2, and 3 are satisfied.

The contaiment isolation activation signal is formed by an "OR" gate of severa! signals, including containment high pressura. Since CVI is initiated by the four automatic contacts discussed in Section 2.2, we conclude that NRC staff criterion no, 4 is satisfied. 
Froil the information provided by the licensee during the August 23, 1979 meeting ${ }^{5}$ and a follow-up telephone call on October 25, 1979 with the NRC, the radiation-monitoring equipment at the Fort Calhoun nuclear power plant is not designed and qualified as safety-grade equipment. We conclude that NRC staff criterion no. 5 is not satisfied.

Resetting of the actuation signal cannot cause the CVI valves to automaticaliy reopen. To reopen these valves, their switches must be reinitiated to the "open" position. We concluut that NRC staff criterion no. 6 is satisfied.

\subsection{OTHER ENGINEEREO SAFETY FEATURE SYSTEM IIRCUITS}

As part of this review and from information obtained from the licensee, it was determined that the design of the containment isolation actuation system, the safety injection actuation system, and the containment spray actuation system are functionally similar to the CVI system. None of these systems have an override feature. The safety injection actuation signal has a "reset" switch, as defined in this report. We conclude that the NRC staff criteria are satisfied. 


\section{CONCLUSIONS}

The EI\&C design aspects of containment purge valve isolation and other ESF signals for Fort Calhoun nuclear power plant were evaluated using thase design criteria stated in jection 2.1 of this report.

We conclude that, with one exception, the CVI system design meets the NRC staff criteria. The single exception is that, on the basis of the information provided, the radiation-monitoring equipment does not meet the NRC staff criterion for safety-grade equipment. We recommend that all of the instrumentation and control systems provided to initiate CVI should be designed and qualified as safety-grade equipment.

We also conclude that the other ESF circuit designs discussed meet the NRC staff criteria. 


\section{REFFRENCES}

1. NRC/DOR letter (A. Schwencer) to OPPD, "Containment. Purging During Normal Plant Operation," dated November 28, 1978.

i. OPPD letter (T. F. Short) to NRC (H. Denton, Attn: R, W. Reid), "Docket 50-285," dated December 28, 1978.

3. OPPD letter (T. E. Shart) to NRC (H. Denton, Attn: R. W. Peid), "Docket 50-285," dated February 8, 1979.

4. OPPD lecter (T. E. Shart) to NRC (H. Denton, Attn: R. W. Reid), "Locket 50-285," dated April 12, 1979.

5. OPPD meeting with NRC in Washington, D. C., "Containment Purging During Normal Plant Operation," held August 23, 1979.

6. U. S. Nuclear Regulatory Comission, Standard Review Plan, "Containment 1solation. Syste:n," NUREG 75/087, Rev. 1, Section 6.2.4. 